\title{
QUALITY OF CLONAL SEEDLINGS OF Tectona grandis Linn F. ROOTED IN DIFFERENT CONCENTRATIONS OF INDOLEBUTYRIC ACID
}

\author{
Maria Angélica Di Carvalho1, Joamir Barbosa Filho², Dagma Kratz ${ }^{3 *}$ \\ ${ }^{1}$ Federal University of Mato Grosso, Graduate Program in Environmental and Forest Sciences, Cuiabá, MT, Brazil, \\ mariangelica.di.carvalho@gmail.com \\ ${ }^{2}$ Forestry engineer, Cuiabá, MT, Brazil, joamirbf@ hotmail.com \\ 3* Federal University of Paraná, Graduate Program in Forest Engineering, Curitiba, PR, Brazil. dagmakratz@ufpr.br
}

Received for publication: 02/05/2018 - Accepted for publicarion: 12/11/2018

\begin{abstract}
Resumo
Qualidade de mudas clonais de Tectona grandis (Linn f.) enraizadas em diferentes concentrações de ácido indolbutírico. Objetivo geral deste trabalho é avaliar o efeito de diferentes concentrações de AIB na sobrevivência em casa de vegetação, casa de sombra e pleno sol, vigor radicial e na qualidade de mudas em Tectona grandis. Para tanto, as miniestacas foram preparadas contendo dois pares de folhas reduzidas a $25 \%$ de sua dimensão original, $(7,0 \pm 1,0 \mathrm{~cm})$ de comprimento e corte em bisel na base. Em seguida foram submetidas a cinco tratamentos com diferentes concentrações de ácido indolbutírico $(0,500,1000,1500$ e 2000 $\mathrm{mg} \mathrm{L} \mathrm{L}^{-1}$ ), permanecendo em casa de vegetação, casa de sombra e a pleno sol por 30 , 20 e 15 dias, respectivamente. Foram avaliadas a sobrevivência em casa de vegetação, casa de sombra e pleno sol; vigor radicial, altura, diâmetro do colo, relação altura/diâmetro do colo, massa seca radicial, aérea e total. O delineamento experimental foi em blocos ao acaso, com cinco repetições de 15 plantas e cinco tratamentos. Os dados foram submetidos ao teste de normalidade, teste de Bartlett e regressão polinomial de segundo grau. Como resultados, verificou-se que a utilização do AIB não influenciou no vigor radicial e na sobrevivência, contudo proporcionou mudas de maior massa seca, sendo o melhor tratamento de $2000 \mathrm{mg} \mathrm{L}^{-1}$.

Palavras-chave: Teca, parâmetros morfológicos, propagação vegetativa, produção de mudas.
\end{abstract}

\begin{abstract}
The general objective of this paper is to evaluate the effect of different IBA concentrations on greenhouse, shade and full sun survival, root vigor and seedling quality in Tectona grandis. To do so, mini-cuttings were prepared containing two pairs of leaves reduced to $25 \%$ of their original size $(7.0 \pm 1.0 \mathrm{~cm})$ in length and bevel cut at the base. They were submitted to five treatments with different concentrations of indolebutyric acid $(0$, 500, 1000, 1500 e $2000 \mathrm{mg} \mathrm{L}^{-1}$ ), remaining in greenhouse, house of shade and in full sun for 30, 20 and 15 days, respectively. Survival was evaluated in greenhouse, house of shade and full sun; radicial vigor, height, diameter of the neck, ratio between shoot height and diameter, root dry mass, aerial, and total mass. The experimental design was in randomized blocks, with five replications of 15 plants and five treatments. Data were submitted to the normality test, Bartlett test and polynomial regression of the second degree. As a result, it was verified that the use of IBA did not influence root vigor and survival, however, it provided seedlings with a higher dry mass, being the best the $2000 \mathrm{mg} \mathrm{L}-1$ treatment.

Keywords: Teak, morphological parameters, vegetative propagation, seedling production.
\end{abstract}

\section{INTRODUCTION}

Tectona grandis Linn F. is the exotic forest species that is standing out in the market due to its high quality wood: it does not bend easily, is resistant to forest fires and attacks by termites and other xylophagous insects (PARK et al., 2016). It has a natural occurrence in deciduous forests of India, Myanmar, North Thailand and Laos, presenting a market value superior to Brazilian mahogany, which can reach US \$3,000.00 per cubic meter sawed (KOLLERT, KLEINE, 2017). In Brazil, commercial plantings of $T$. grandis have increased steadily in recent years, reaching 87,502 thousand hectares in 2016. It represents an increase of $25 \%$ when compared to the year of 2010, according to the Brazilian Tree Industry (IBA, 2017).

The seedlings of $T$. grandis (high genetic variability) have slow and irregular germination due to mechanical numbness, leading to an initial development in heterogeneous field (FERREIRA et al., 2016), which may reflect negatively on seedlings productivity and silvicultural treatments. In turn, these limitations can be minimized through vegetative propagation techniques. Whence, they consist of producing from selected genotypes, seedlings with economically desired characteristics and can be applied, in addition, to any individual that does not produce fertile seeds, either because they have not entered the mature stage yet or as a result of unfavorable environmental conditions (PARK et al., 2016). 
The micropropagation in T. grandis has already been described by some authors (FERNANDES et al., 2013; TAMBARUSSI et al., 2017). These studies show that the rooting performed in vitro produces the most fragile roots, which after transferring the seedlings to an ex vitro environment, they do not survive, increasing, then, production costs (FERRI et al., 1998). While the minicutting technique aims to increase productivity, reduce genetic variability, it has a low production cost, lower concentrations of plant regulator, reduced rooting time and greater survival in the acclimation phase of the seedlings (XAVIER et al., 2013; WENDLING, et al., 2014).

Among the factors that interfere in the quality of the vegetative propagules, the radicial force has direct interference, acting on the physiological vigor and quality of seedlings produced asexually. However, there are some ways that can maximize the rooting of vegetative propagules, being the phytorregulator, indolebutyric acid (IBA), the one which helps to promote adventitious roots, due to its lower mobility and greater chemical stability inside the minicut (HARTMANN et al., 2011; XAVIER et al., 2013). Its concentration may vary according to species, clone, maturation status, type of stake, environmental conditions, form and time of application (XAVIER et al., 2013).

For T. grandis, there are some authors who report the use of IBA in the rooting of minicuttings, nonetheless, there are differences as to the necessity of its application, as demonstrated by Badilla et al. (2016). In order to do so, one must take into account the juvenile degree of the vegetative material, the age of the ministumps, the genetic material differences and the environmental conditions (HARTMANN et al., 2011).

Although studies have demonstrated the influence of IBA on the rooting of minicuttings of T. grandis, there are no studies in the literature that evaluate their relation with the quality of the formed seedling, as observed to other forest species, such as: Theobroma cacao L. (SANTOS JÚNIOR et al., 2008); Cariniana estrellensis (Raddi) Kuntze) (GATTI et al., 2011), and Handroanthus heptaphyllus Mattos (OLIVEIRA et al., 2015).

Therefore, it is necessary to verify the influence of the IBA on root vigor and on the quality of the seedling of $T$. grandis, since minicuttings treated with this phytoregulator tend to form a more vigorous root system, resulting in better seedlings quality in questions of height, diameter, and dry mass. Thus, the objective of this study was to evaluate the effect of different concentrations of IBA in the survival in greenhouse, shade house, and full sun, as much as root vigor and quality of Tectona grandis seedlings.

\section{MATERIAL AND METHODS}

The study was carried out in the nursery of Floresteca SA, located in the municipality of Rosário West, Mato Grosso State, Brazil, from the period of March to July 2016. According to the classification of KöppenGeiger, the climate of the region is type Aw (tropical climate with dry winter season). The annual rainfall average is $1400 \mathrm{~mm}$, with an annual temperature average of $26.5^{\circ} \mathrm{C}$ in the summer and $22.5^{\circ} \mathrm{C}$ in the winter (ALVARES et al, 2013).

\section{Constitution and management of the clonal minigarden}

As a source of propagules for minicuttings, micropropagated mini-stumps with one year and three months of age were used. The genetic material used came from selected genotypes in commercial plantations in Brazil.

The clonal minigarden of $T$. grandis was installed in a greenhouse with an average temperature of $35^{\circ} \mathrm{C}$ and relative humidity of $45 \%$. The mini-stumps were placed in $10 \times 10 \mathrm{~cm}$ spacing in fiber cement boards with asbestos $20 \mathrm{x} 1 \mathrm{~m}$ (length $\mathrm{x}$ width), filled with gravel at the bottom and washed sand of medium particle size $(0.10$ $\mathrm{mm}<$ particle diameter $<0.25 \mathrm{~mm}$ ) at the top of the minigarden.

Moreover, the minigarden's nutritional solution was applied by an automated drip fertigation system, activated twice a week, in which each mini-stump received $100 \mathrm{~mL}$ per application. In this way, the nutrient solution was composed of calcium nitrate $\left(0.08 \mathrm{mg} \mathrm{L}^{1}\right)$, ammonium nitrate $\left(0.07 \mathrm{~g} \mathrm{~L}^{1}\right)$, magnesium sulfate $(0.06 \mathrm{~g}$ $\left.\mathrm{L}^{1}\right)$, potassium chloride $(0.29 \mathrm{~g} \mathrm{~L}-1)$, zinc sulfate $(0.004 \mathrm{~g} \mathrm{~L}-1)$, manganese sulfate $\left(0.001 \mathrm{~g} \mathrm{~L}^{1}\right)$, sodium molybdate (0.001 $\left.\mathrm{g} \mathrm{L}^{1}\right)$, boric acid $\left(0.001 \mathrm{~g} \mathrm{~L}^{1}\right)$, copper sulfate $\left(0.011 \mathrm{~g} \mathrm{~L}^{1}\right)$, and ferrous sulfate $\left(1.3 \mathrm{~g} \mathrm{~L}^{1}\right)$. The irrigation of the minigardem was performed by an aspersion system, activated every 30 seconds.

\section{Collection of sprouts and preparation of minicutings}

To preserve the turgidity condition of the plant tissue, the sprouts were conditioned in a container with water until the preparation of minicuttings, application of the treatments, and planting. This period was up to 15 minutes. Harvesting was carried out in the morning, in order to avoid the loss of humidity from the sprouts.

After the collection of the sprouts in the clonal minigarden, the minicuttings were prepared with $7.0 \pm 1.0$ $\mathrm{cm}$ without the removal of the apical bud. In the basal region, the bevel cut was performed, maintaining two pairs of leaves reduced to $25 \%$ of their original size, avoiding, then, the excess of transpiration and the difficulty of reaching the substrate (Figure 1). 

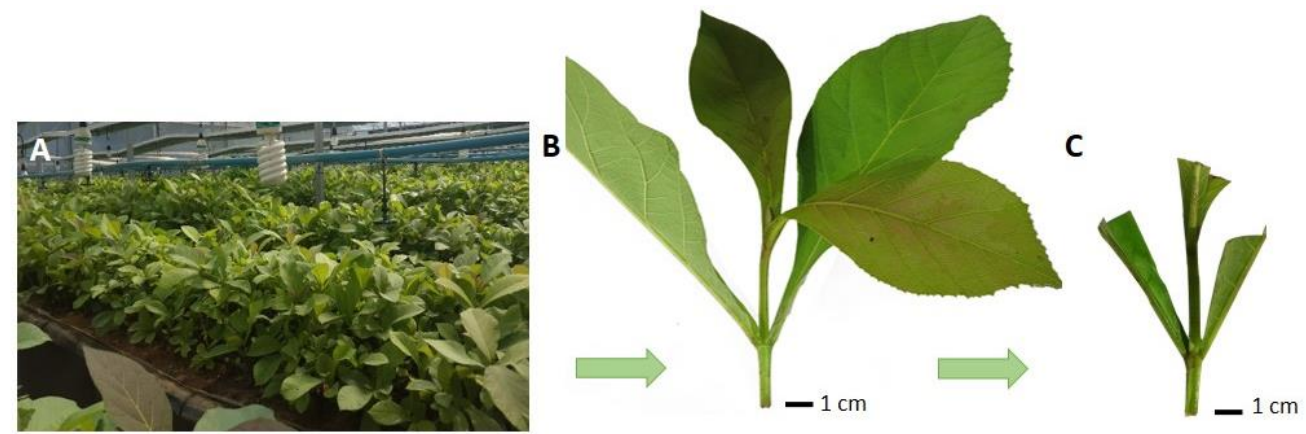

Figura 1. Representação esquemática do preparo das miniestacas em Tectona grandis Linn $F$. A: minijardim clonal em canaletão. B: broto. C: miniestaca com folhas reduzidas à $25 \%$ de sua dimensão original.

Figure 1. Schematic representation of mini-cutting preparation in Tectona grandis Linn F. A: clonal mini-garden. B: shoots. C: mini-cutting with leaves reduced to $25 \%$ of their original size.

\section{Application of different concentrations of IBA and planting minicuttings}

In order to evaluate the effect of IBA on rooting, root vigor and seedling quality, the treatments used were $0.500,1000,1500$, and $2000 \mathrm{mg} \mathrm{L}^{-1}$, being these concentrations defined based on their usability and success in other forest species and production companies of $T$. grandis seedlings. The application of auxin was via talc, placing a small portion at the base of the minicut. For the preparation of IBA, a high precision balance was used for weighing the phytorregulator and neutral talc, then adding one liter of $98 \%$ alcohol, the conversions were made for each concentration.

After application of IBA, minicuttings were staked in $55 \mathrm{~cm}^{3}$ plastic tubes, filled with Tecnomax ${ }^{\circledR}$ commercial substrate, which is composed of composted pine bark, coconut fiber, carbonized rice husk, expanded vermiculite and charcoal as well as hydrogenation potential of 6.0 , average humidity of $52 \%$, cation exchange capacity of $200 \mathrm{mmol}_{\mathrm{c}} / \mathrm{dm}^{-3}$ and electrical conductivity of $0.7+/-0.3(\mathrm{~ms} / \mathrm{cm})$ (information extracted from the product label). Three-month controlled release fertilizer with following contents: $1.1 \mathrm{~g} \mathrm{~L}^{-1}$ of nitrogen; $1.04 \mathrm{~g} \mathrm{~L}^{-1}$ of phosphate; $0.850 \mathrm{~g} \mathrm{~L}^{-1}$ of potassium; $0.020 \mathrm{~g} \mathrm{~L}^{-1}$ of magnesium; $0.140 \mathrm{~g} \mathrm{~L}^{-1}$ of sulfur; $0.004 \mathrm{~g} \mathrm{~L}^{-1}$ of manganese; $0.004 \mathrm{~g} \mathrm{~L}^{-1}$ of copper; $0.005 \mathrm{~g} \mathrm{~L}^{-1}$ of molybdenum; $0.001 \mathrm{~g} \mathrm{~L}^{-1}$ of boron; $0.002 \mathrm{~g} \mathrm{~L}^{-1}$ of iron, and $0.001 \mathrm{~g} \mathrm{~L}^{-1}$ of $^{-1}$ zinc, were used for soil fertilization.

The minicuttings, after planting, were conditioned in greenhouse $(\mathrm{GH})$ covered with transparent polyethylene and nettled shade with $50 \%$ reduction of luminosity in the ceiling, average temperature of $37.5^{\circ} \mathrm{C}$, relative humidity of air superior to $85 \%$, and irrigation by micro aspersion system activated every 30 minutes for 20 seconds in the first week and from the second week on, every 45 minutes for 20 seconds, remaining in this environment for 30 days.

For acclimatization, the seedlings were transferred to shade house ( $\mathrm{SH}$ ) covered with nettled shade $50 \%$ reduction of luminosity in the walls and ceiling and irrigation by micro aspersion every six hours for five minutes, in which it remained for 20 days. Subsequently, they were allocated in the growth site in full sun (FS) for 15 days and irrigated by asperse twice a day for 15 minutes.

\section{Effect of IBA on survival, root vigor and seedling quality}

The percentages of minicuttings survival at the exit of the greenhouse (EGH), shade house (ESH) and full sun (EFS), 30, 50 and 65 days after planting, respectively, were evaluated. The minicuttings were considered as alive when they maintained a green coloration, with or without new sprouts.

After exiting the greenhouse, the minicuttings root vigor was evaluated, randomly extracting five plants per replicate. The number of roots (NR), total length of primary roots $(\mathrm{cm})(\mathrm{TLR})$ and length of the largest primary root $(\mathrm{cm})(\mathrm{L}>\mathrm{R})$ were measured using a millimeter ruler.

To evaluate the quality of the seedlings produced at 65 days after planting, at the time of exiting the seedlings from the full sun area, biometric variables were measured: shoot area height $(\mathrm{cm})(\mathrm{H})$, stem diameter $(\mathrm{mm})(\mathrm{D})$, root dry mass (RDM), aerial dry mass (ADM) and total dry mass (TDM) $\left(\mathrm{mg} \mathrm{plant}^{-1}\right)$. For the calculation of seedling quality index, the ratio between shoot area height and stem diameter (H/D) was used.

To measure the diameter and height, a digital caliper (accuracy of $0.01 \mathrm{~mm}$ ) and a millimeter ruler were used, respectively. To quantify the dry mass, a forced air circulation oven was used at $105^{\circ} \mathrm{C}$ for 48 hours.

\section{Experimental design and statistical analysis of data}

The experimental design was a randomized complete block with five replications of 15 plants per plot and 5 treatments. Statistical analyzes were carried out with the support of the Assistat version 7.7. and Microsoft 
Excel version 2013 programs. The variables were submitted to the normality test, Bartlett test ( $\mathrm{p}<0.05)$, in order to verify homogeneity between treatments, analysis of variance (ANOVA) ( $\mathrm{p}<0.05$ ), and polynomial regression analysis.

\section{RESULTS}

Regarding the root analyzes, root number, total length of primary root, survival at the exit of greenhouse, shade house and area in full sun, there was no significant difference between the different concentrations of IBA, with averages of $1.70 ; 6.46 \mathrm{~cm}, 96.27 \%, 90.93 \%$, for, respectively, NR, TLR, EGH, ESH and EFS (Table 1). For the largest primary root length, it was observed a significant effect $(\mathrm{p}<0.05)$ of IBA concentrations (Figure 2), with the best result being a concentration of $500 \mathrm{mg} \mathrm{L}^{-1}$ at $2.91 \mathrm{~cm}$.

Tabela 1 - Análise de variância para sobrevivência na saída da casa de vegetação (SSCV), saída da casa de sombra (SSCS) e saída a pleno sol (SSPS), número de raízes (NR), comprimento total de raízes (CTR), comprimento da maior raiz $(\mathrm{C}>\mathrm{R})$ em função das concentrações de AIB, em um clone de Tectona grandis Linn F.

Table 1 - Analysis of variance for survival at the exit of the greenhouse (EGH), exit of the shade house (ESH) and exit at full sun (EFS), number of roots (NR), total length of roots (TLR), length of the largest $\operatorname{root}(\mathrm{L}>\mathrm{R})$ as a function of IBA concentrations in a clone of Tectona grandis Linn $F$.

\begin{tabular}{|c|c|c|c|c|c|c|c|}
\hline \multirow{3}{*}{$\begin{array}{l}\text { Cause of } \\
\text { variation }\end{array}$} & \multirow{3}{*}{ GL } & \multicolumn{6}{|c|}{ Medium Squares } \\
\hline & & EGH & ESH & EFS & NR & TLR & $\mathbf{L}>\mathbf{R}$ \\
\hline & & \multicolumn{3}{|c|}{$\%$} & & \multicolumn{2}{|c|}{$(\mathrm{cm})$} \\
\hline IBA & 2 & $4.93^{\mathrm{ns}}$ & $7.77^{\mathrm{ns}}$ & $20.57^{\mathrm{ns}}$ & $0.14^{\mathrm{ns}}$ & $1.37^{\mathrm{ns}}$ & $0.11 *$ \\
\hline Residue & 2 & 1.12 & 21.38 & 26.72 & 0.14 & 0.74 & 0.00 \\
\hline Average & - & 96.27 & 90.93 & 87.47 & 1.70 & 6.46 & 2.70 \\
\hline $\mathrm{GH}(\%)$ & - & 4.51 & 7.88 & 9.42 & 21.78 & 15.87 & 8.95 \\
\hline
\end{tabular}

Caption: ${ }^{\mathrm{ns}}=$ non-significant at $5 \%$ probability by the $\mathrm{F}$ test; $*=$ significant at $5 \%$ by the $\mathrm{F}$ test.

Regarding the quality of the seedling (Table 2), it was verified that higher concentrations of IBA (2000 $\mathrm{mg} \mathrm{L}^{-1}$ ) favored the increment of root dry, aerial and total mass. Nonetheless, for height and ratio between shoot height and stem diameter the concentration of $1500 \mathrm{mg} \mathrm{L}^{-1}$ obtained better results, with $6.79 \mathrm{~cm}$ and 1.22 , respectively (Figure 2). Only the variable diameter of the stem (D) did not present a significant difference, obtaining an average of $0.56 \mathrm{~cm}$ (Table 2).

Tabela 2 - Análise de variância para qualidade da muda nas variáveis: altura (H), diâmetro do colo (D), razão entre altura da parte aérea e diâmetro do colo (Ht/D), massa seca radicial (MSR), massa seca parte aérea (MSA) e massa seca total (MST), em função das concentrações de AIB, em um clone de Tectona grandis Linn F.

Table 2 - Analysis of variance for seedling quality in the variables height $(\mathrm{H})$, diameter of the stem (D), ratio between shoot height and diameter (Ht/D), root dry mass (RDM), aerial dry mass (ADM) and total dry mass (TDM), as a function of IBA concentrations in a Tectona grandis Linn F. clone.

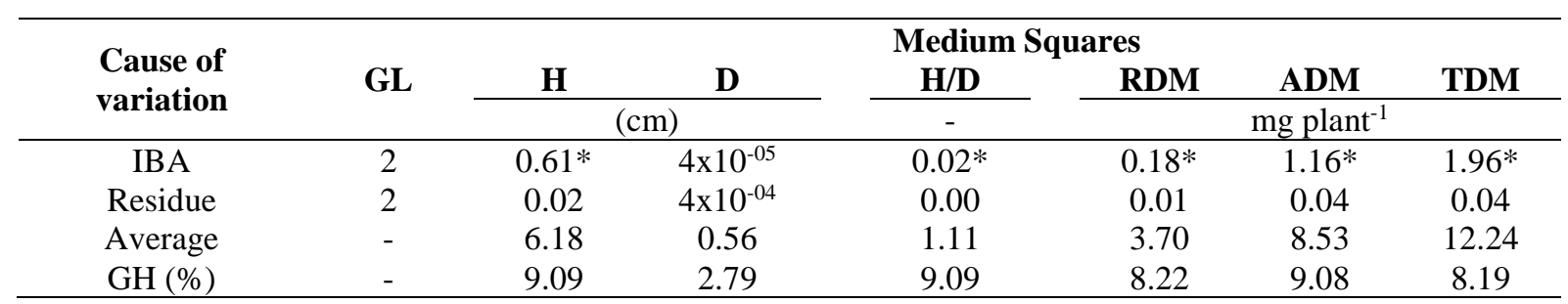

Caption: $^{\mathrm{ns}}=$ non-significant at $5 \%$ probability by the $\mathrm{F}$ test; $*$ significant at $5 \%$ by the $\mathrm{F}$ test. 

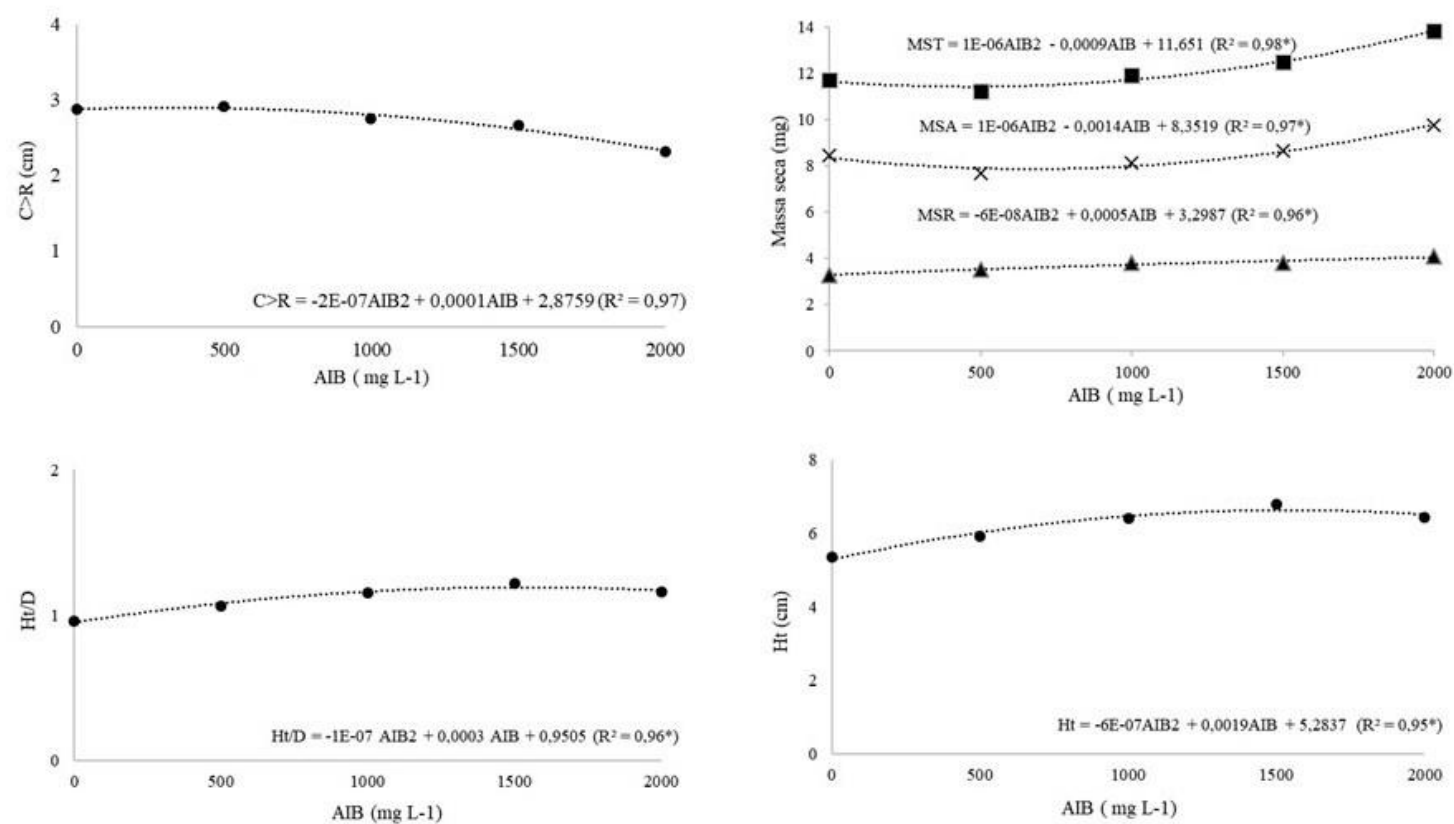

Figura 2. Variáveis em que houve diferença significativa entre as concentrações de AIB aplicadas. A: comprimento da maior raiz primária $(\mathrm{C}>\mathrm{R})(\mathrm{cm})$; B: massa seca total $(\mathrm{MST})$, massa seca da parte aérea (MSA) e massa seca radicial (MSR); C: razão entre altura da parte aérea e diâmetro do colo (Ht/D) e D: altura em um clone de Tectona grandis Linn $F$.

Figure 2. The variables were improved between the applied IBA spheres. A: length of the largest primary root $(\mathrm{C}>\mathrm{R})(\mathrm{cm})$; B: root dry mass (RDM), aerial dry mass (ADM), and total dry mass (TDM); C: reason between shoot height and stem diameter $(\mathrm{Ht} / \mathrm{D})$, and $\mathrm{D}$ : height $(\mathrm{Ht})(\mathrm{cm})$ in a Tectona grandis Linn $\mathrm{F}$ clone.

It should be emphasized that it was not possible to estimate the dose of maximum technical efficiency, since it was not obtained an inflection point in the curves within the limits of the treatments.

\section{DISCUSSION}

Regarding survival, the results found in this study corroborate with that observed by Badilla et al. (2016) in T. grandis, and with Oliveira et al. (2016) in $H$. heptaphyllus, IBA does not influence the survival of minicuttings.

The high survival rates with a mean of $91.5 \%$ in all stages of seedlings production may be associated with the youthfulness of the vegetative material used (HARTMANN et al., 2011; WENDLING et al., 2014), inasmuch as the mini-stumps were one year and three months old and micropropagated. According to Husen (2011), T. grandis decreases survival percentage in the minicutting according to the age of the donor plant. They advise matrices of up to 4 years old in order to achieve high survival and rooting, even though applying IBA in minicuttings originating from matrices with more than 15 years of age (HUSEN; PAL 2007b).

The high GH survival (96.27\%) (Table 1) shows good nutritional conditions of the mini-stumps, which is resulted from adequate management in the clonal minigarden (XAVIER et al., 2013) and in GH, SH and FS. It corroborates with the findings of Moraes et al. (2014), in which nebulized environment with humidity control showed better survival percentages for Toona ciliata M. Roemer. Additionally, it can also be inferred that the endogenous hormonal balance of the minicutting was sufficient to induce root emission, without the need for exogenous application of IBA, favoring, then, good survival results.

The water restriction does not cause significant losses in the survival of seedlings in T. grandis, because it presents a stomata high sensitivity, closing them and thus reducing its leaf area (MATOS et al., 2018). However, in this study there is a decrease in survival values in GH, SH and FS (Table 1), a fact also observed by Badilla et al. (2016) for $T$. grandis in the passage of GH and SH seedlings, $95.37 \%$ and $89.93 \%$ respectively, and Meza $e t$ al. (2015) $87.5 \%$ in $\mathrm{GH}$ and $69.39 \%$ in $\mathrm{SH}$.

In relation to the root vigor (Table 1), only the $\mathrm{L}>\mathrm{R}$ was significantly different, with the highest results at the concentration of $500 \mathrm{mg} \mathrm{L}^{-1}$ (Figure 2). A similar result to that found by Oliveira et al. (2015) in H. heptaphyllus 
(mean of $24.7 \mathrm{~cm}$ TLR and $5 \mathrm{NR}$ ), in which IBA did not influence the length and number of primary roots, only the number of secondary roots.

For other authors (HUSEN; PAL, 2007a; MEZA et al., 2015), higher results were obtained with IBA application in $T$. grandis for variables related to root vigor. The necessity of phytorregulator applications depends mainly on the genetic material and degree of youthfulness of the propagule (HARTMANN et al., 2011). In the case of $T$. grandis, the number of roots under the IBA application conditioner is influenced by the age of the propagule plant doner (HUSEN; PAL, 2007b).

Moreover, regarding the seedling quality at the time of shipment, the diameter was the only variable that did not present a significant difference, behaving in an expected way, since the plants invest first in the height growth, to later expand the diameter. The homogeneity of the diameter between the seedlings of all treatments can be verified by checking the low value of the coefficient of variation (2.79\%). The authors Badilla et al. (2016) and Fernandes et al. (2015) also observed in $T$. grandis that the diameter was not affected when subjected to different concentrations of IBA.

For the other variables $\mathrm{Ht}, \mathrm{Ht} / \mathrm{D}, \mathrm{RDM}, \mathrm{ADM}$ and TDM, the application of IBA presented a fundamental role for seedling quality, considering that for the dry matter the concentration of $2000 \mathrm{mg} \mathrm{L}^{-1}$ obtained higher values (Figure 2). In general, it can be seen in the graph (Figure 2), except for $\mathrm{L}>\mathrm{R}$, the growth of the polynomial curve according to the increase of IBA concentrations, which, therefore, explains the impossibility of finding the maximum technical efficiency dosage within the concentrations tested.

Furthermore, it can be inferred that with the increase of IBA concentrations, a root system is obtained with greater vigor, considering the amount of secondary roots and diameter of the primary roots, facilitating, as a result, the uptake of water and nutrients from the substrate and consequently a better aerial development. In the same way as the positive correlation between the amount of secondary roots and IBA concentration in stakes of H. heptaphyllus (OLIVEIRA et al., 2015).

According to Hartmann et al. (2011), among the main biological functions of auxins, it is possible to cite their influence on growth and especially for $T$. grandis it was pointed out in the root segment, being observed in the $\mathrm{L}>\mathrm{R}$, and in the increase of dry mass to detriment of the best root system. In this way, the supply of exogenous IBA promoted a hormonal alteration, contributing to increase the synthesis of carbohydrates, which are the main source of energy available to the root development and can represent up to $75 \%$ of the dry mass in woody species (LATT et al., 2001).

Pacheco and Franco (2008) highlight that stakes treated with IBA promote an increase in root length and may be related to changes in the extensibility of the cell wall by the activation of the protein called expansins. Therefore, these, to be activated, depend on the action of auxins on H+-ATPases proteins of the plasma membrane, the ones which increase the activity in the presence of auxins (TAIZ; ZEIGER, 2004).

As observed by Husen and Pal (2007b) in a study developed with T. grandis, it was found higher levels of carbohydrates and proteins in stakes treated with IBA and NAA (naphthalene acetic acid) originated from matrices of seminal origin with 2 months of age. According to these authors, carbohydrates, mainly sugars and starches, are mobilized by hydrolytic enzymatic activity, being translocated to the rooting region of the stake, where they will be used to provide the energy necessary for cell division and differentiation, preceding the appearance of roots.

Thus, based on the results of this study, the IBA promoted crucial importance for good seedling quality, being expressed by increased dry, aerial and total dry mass gain. Forest plantations present better survival and establishment rates the larger the root system and, consequently, the better aerial development, facilitating the photosynthetic activity.

\section{CONCLUSION}

- For the concentrations of IBA used, the phytorregulator does not interfere in the root vigor referring to total root length and number of roots.

- The concentration of $500 \mathrm{mg} \mathrm{L}^{-1}$ provides higher primary root growth.

- The use of IBA does not influence survival in all stages of seedling production, however, it provides the formation of seedlings with better physiological and morphological quality.

Greater dry mass accumulation is obtained with the use of IBA $2000 \mathrm{mg} \mathrm{L}^{-1}$.

\section{REFERENCES}

ALVARES, C. A.; STAPE, J.L.; SENTELHAS, P.C.; GONÇALVES, J. L. M., SPAROVEK, G. Köppen's climate classification map for Brazil. Meteorologische Zeitschrift, Stuttgart - Germany, v. 22, n.6, p. 711 - 728, 2013. 
BADILLA, Y.; XAVIER, A.; MURILLO, O.; PAIVA, H. N. Iba efficiency on mini-cutting rooting from teak (Tectona grandis linn f.) Clones. Revista Árvore, Viçosa-MG, v.40, n.3, p.477-485, 2016.

FERNANDES, D. A.; AZEVEDO, P. H.; COSTA, R. B.; BRONDANI, G. E. Tipos de vedação e concentrações de sacarose no cultivo in vitro de Tectona grandis L.f. Revista de Agricultura. Piracicaba - SP, v.88, n.3, p. 218 $-228,2013$

FERNANDES, D. A.; MARTINEZ, D. T.; COSTA, R. B. Sacarose e ácido indolbutírico no enraizamento de Tectona grandis 1.f. Revista de Agricultura, v.90, n.1, p. 87 - 99, 2015.

FERRI, V. C.; CENTELLAS, A. Q.; HELBIG, V. E.; FORTES, G. R. L. Uso de ágar, amido e ácido indolbutírico no enraizamento in vitro do porta-enxerto de macieira MM 111. Ciência Rural, Santa Maria, v. 28, n. 4, p. 561$565,1998$.

FERREIRA, R. Q. S.; CAMARGO, M. O.; SOUZA JUNIOR, M. R.; SOUZA, P. B.; OLIVEIRA, L. M. Choque térmico na superação da dormência de diásporos de Tectona grandis L. f. Scientia Plena, Tocantins, v. 12, N. 03, 2016.

GATTI, K. C.; GONÇALVES, R. C.; XAVIER, A.; PAIVA, H. Propagação vegetativa de Jequitibá (Cariniana estrellensis (Raddi) por miniestaquia. Temas Agrários, Córdoba, v. 16, n. 2, p. 54-63, 2011.

HARTMANN, H. T.; KESTER, D. E.; DAVIES JUNIOR, F. T.; GENEVE, R. L. Plant propagation: principles and practices. New Jersey: Prentice Hall, 8 Ed. 2011. p. 915.

HUSEN, A.; PAL, M. Effect of branch position and auxin treatment on clonal propagation of Tectona grandis Linn. f. New Forests v. 34, p. 223-233, 2007 a.

HUSEN, A.; PAL, M. Metabolic Changes during Adventitious Root Primordium Development in Tectona grandis Linn. f. (Teak) Cuttings as Affected by Age of Donor Plants and Auxin (IBA and NAA) Treatment. New Forests, v. 33, p. 309-323, 2007 b.

HUSEN, A. Rejuvenation and Adventitious Rooting in Coppice-Shoot Cuttings of Tectona grandis as Affected by Stock-Plant Etiolation. American Journal of Plant Sciences, Ethiopia, v. 2, p. 370-374, 2011.

HUSEN, A. Multiplication of Teak (Tectona grandis) by Using Moderately Hard Stem Cuttings: Effect of Genotypes (FG1 and FG11 Clones) and IBA. Advances in Forestry Letters (AFL), Gondar V. 2, Issue 2, June, 2013.

INDUSTRIA BRASILEIRA DE ÁRVORES. Relatório IBÁ 2017 Indústria brasileira de árvores. [s.l: s.n.]. Disponível em: http://iba.org/images/shared/Biblioteca/IBA_RelatorioAnual 2017.pdf

KOLlERT, W.; KLEINE, M. The Global Teak Study - Analysis, Evaluation and FuturePotential of Teak Resources. Austria, 2017, 107 p.

LATT, C.R. et al. Reserve carbohydrate levels in the boles and structural roots of five multipurpose tree species in a seasonally dry tropical climate. Forest Ecology and Management, v.146, p.145-158, 2001.

MATOS, F. S.; FREITAS, I. A. S.; SOUZA, B. R.; LOPES, V. A.; ROSA, V. R. Crescimento de plantas de Tectona grandis sob restrição hídrica. Revista Agrarian, Dourados - MS, v.11, n.39, p. 14-21, 2018.

MORAES, D. G.; BARROSO, D. G.; FIGUEIREDO F. A. M. M. A.; SILVA T. R. C.; FreitAS, T. A. S. Enraizamento de miniestacas caulinares e foliares juvenis de Toona ciliata M. Roemer. Magistra, Cruz das Almas - BA, V. 26, n. 1, p. $47-54,2014$.

OLIVEIRA, T. P. F.; BARROS, D. G.; LAMÔNICA, K. R.; CARVALHO, V. S.; OLIVEIRA, M. A. Efeito do ácido indol-3-butírico (aib) no enraizamento de miniestacas de ipê-roxo (Handroanthus heptaphyllus Mattos). Ciência Florestal, Santa Maria, v. 25, n. 4, p. 1043-1051, 2015.

PACHECO, J. P.; FRANCO, E. T. H. Ácido indolbutírico em diferentes diâmetros na estaquia de Luehea divaricata. Ciência Rural, Santa Maria, v.38 n.6, 2008.

PARK, Y.; BONGA, J. M.; MOON H. Vegetative Propagation of Forest Trees. In: GOH, D., MONTEUUIS, O. Teak. National Institute of Forest Science (NIFoS), Seoul, Korea, p 425-440. 2016. 
SANTOS JÚNIOR, A. J.; ALMEIDA, A. F.; SILVA, D. C.; FARIA, J. C.; MIELKE, M. S.; GOMES F. P. Enraizamento de estacas, crescimento e respostas anatômicas de mudas clonais de cacaueiro ao ácido indol-3butírico. Revista Brasileira de Fruticultura, Jaboticabal - SP, v. 30, n. 4, p. 1071-1082, 2008.

TAMBARUSSI E. V.; ROGALSKI M.; GALEANO E.; BRONDANI G. E.; MARTIN V. F.; SILVA L. A.; CARRER, H. Efficient and new method for Tectona grandis in vitro regeneration. Crop Breed. Appl. Biotechnol. Viçosa - MG, v.17, n.2, 2017.

TAIZ, L.; ZEIGER, E. Fisiologia vegetal. Porto Alegre: Artmed, 2004. 719p

WENDLING, I.; TRUEMAN, S. J.; XAVIER, A. Maturation and related aspects in clonal forestry -Part I: concepts, regulation and consequences of phase change. New Forest, West Lafayette, v. 45, p. 449-471, 2014.

XAVIER, A.; WENDling, I.; SILVA, R. L. Silvicultura Clonal: Princípios e Técnicas. 2ed. Viçosa: UFV, 2013, p 279. 